\title{
UJI AKTIVITAS EKSTRAK ETANOL DAUN KECOMBRANG (Etlingera elatior (Jack)R.M.Sm) SEBAGAI PERTUMBUHAN RAMBUT TERHADAP KELINCI PUTIH JANTAN
}

\author{
${ }^{1}$ Ai Siti Nurlatifah, ${ }^{2}$ Ilham Alifiar, ${ }^{3}$ Fajar Setiawan
}

Program Studi S1 Farmasi Sekolah Tinggi Ilmu Kesehatan Bakti Tunas Husada Tasikmalaya

Info Article ABSTRAK

\section{Submitted :}

15 September 2020

Revised:

13 Januari 2021

Accepted :

13 Januari 2021

\section{Corresponding Author :}

Ilham Alifiar

\section{Email :}

ilhamalifiar@stikes-bth.ac.id
Kerontokan rambut yang sering diakhiri dengan kebotakan merupakan problema estetis yang sangat dikhawatirkan setiap orang. Rambut sehat mempunyai siklus pertumbuhan rambut yang panjang dan kelembaban yang cukup dimana pertumbuhan rambut terjadi karena sel-sel daerah matriks atau umbi rambut secara terus menerus membelah. Bahan alam yang diperkirakan berpotensi dalam pertumbuhan rambut adalah daun kecombrang (Etlingera elatior (Jack) R.M.Sm). Penelitian ini bertujuan untuk mengetahui aktivitas ekstrak etanol daun kecombrang terhadap pertumbuhan rambut kelinci putih jantan dan konsentrasi mana yang memiliki aktivitas paling baik. Dalam penelitian ini dilakukan 6 perlakuan yaitu kontrol normal, kontrol negatif, kontrol positif, ekstrak etanol daun kecombrang konsentrasi 2,5\%, konsentrasi 5\% dan konsentrasi $10 \%$. Perlakuan dilakukan setiap hari dengan volume pengolesan $1 \mathrm{~mL}$ setiap konsentrasi selama 28 hari. Pengukuran panjang rambut dilakukan pada hari ke 7, 14, 21 dan 28 menggunakan jangka sorong dan pengukuran bobot rambut dilakukan pada hari ke 28 dengan cara mencukur rambut yang tumbuh kemudian ditimbang. Data yang diperoleh diolah secara statistik dengan metode Anova. Hasil penelitian menunjukkan bahwa ekstrak etanol daun kecombrang 10\% memiliki aktivitas sebagai penyubur rambut yang paling baik dengan rata-rata panjang rambut $1,40 \mathrm{~cm}$. Hasil analisa statistik menunjukkan adanya perbedaan yang bermakna pada konsentrasi $10 \%$ ekstrak etanol daun kecombrang terhadap aktivitas pertumbuhan rambut kelinci dengan kontrol negatif dan kontrol normal.

Kata kunci: Ekstrak etanol daun kecombrang (Etlingera elatior (Jack) R.M.Sm), Pertumbuhan rambut, Minoxidil
Access this article

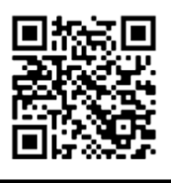

SCAN ME

\section{ABSTRACT}

Hair loss affects one's self image and emotional well-being. It is a very real and serious aesthetic concern for everyone. Healthy hair has a long cycle of hair growth and sufficient moisture where hair growth occurs because the cells of the matrix region or hair bulbs are continuously cleaving. Natural ingredients that are estimated to have potential in hair growth are kecombrang leaves (Etlingera elatior (Jack) R.M.Sm). The purpose of this study was to determine the activity of the ethanol extract kecombrang leaves to the growth 
of white male rabbit hair and which concentration had the most optimum activity. In this study we determine six treatment: normal control, negative control, positive control, ethanol extract kecombrang leaves of concentration $2,5 \%$, concentration $5 \%$ and concentration $10 \%$. The treatment is done every day with the volume every time the basting of one mili liter each plot every day for twenty one days. Hair Length measurements performed on days 7 th, 14th, 21th and 28nd using calipers and the hair weight measurements performed on day 28 by way of shaved hair grows and then weighed. The data obtained were processed statistically by ANOVA methods. The results showed that ethanol extract of $10 \%$ kecombrang leaves had the best hair fertilizer activity with an average hair length of $1,40 \mathrm{~cm}$. The results of statistical analysis showed a significant difference in the concentration of $10 \%$ ethanol extract of kecombrang leaves on rabbit hair growth activity with negative control and normal normal.

Keywords: Ethanol extract kecombrang leaves (Etlingera elatior (Jack) R.M. Sm), hair growth, Minoxidil

\section{PENDAHULUAN}

Rambut merupakan mahkota yang berfungsi untuk memberikan kehangatan, perlindungan dan penunjang penampilan. Salah satu masalah yang paling dikhawatirkan setiap orang adalah kerontokan pada rambut yang dapat mengakibatkan kebotakan sehingga menyebabkan rasa percaya diri hilang (Diana, 2014).

Di United States kejadian rambut rontok menimpa 50 juta orang dan 20 juta diantaranya adalah wanita. Penyebabnya beraneka ragam, salah satunya oleh kosmetik rambut. Rambut rontok akibat kosmetik banyak dijumpai pada wanita Afrika-Amerika. Penggunaan bahan pelurus rambut menyebabkan kerontokan dan kerusakan pada $95 \%$ penggunanya di Amerika dan 53\% di Nigeria (Umborowati dan Rahmadewi, 2012).

Cara yang dilakukan untuk menyelesaikan masalah kerontokan salah satunya dengan menggunakan sediaan kosmetik berupa cairan penumbuh rambut yang berasal dari sintesis yaitu Minoxidil'. Namun seringkali obat yang berasal dari sintesis dapat menimbulkan efek samping, sehingga banyak cara yang dilakukan untuk mengurangi efek samping tersebut dengan menggunakan bahan dari alam (Aprilia, 2017). Salah satunya yang diduga dapat memicu pertumbuhan rambut adalah kecombrang dimana tumbuhan ini dimanfaatkan sebagai penyubur rambut di wilayah kabanjahe oleh balita batita yang pertumbuhan rambutnya lamban (Turnip, 2019). Senyawa yang diduga dapat menjadi penyubur rambut yaitu flavonoid, alkaloid, tanin (Bylka, 2013). Kecombrang umumnya tumbuh di daratan rendah di daerah tropika basah, dapat ditemukan pada ketinggian sampai 2700 mdpl (Yeats, 2015). Penelitian ini bertujuan untuk mengetahui aktivitas ekstrak etanol daun kecombrang terhadap pertumbuhan rambut dan untuk mengetahui pada konsentrasi berapa ekstrak etanol daun kecombrang dapat memberikan efek pada pertumbuhan rambut. 


\section{METODE PENELITIAN}

\subsection{Alat}

Menggunakan oven (Memmet), blender (Philips), timbangan analitik (mettle toledo), gelas kimia $500 \mathrm{~mL}$

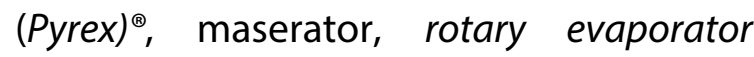
(EYELA OSB-2100), jangka sorong, tabung reaksi (Pyrex), cawan uap, gunting. Seperangkat Notebook dengan software SPSS untuk analisa data.

\subsection{Bahan}

Menggunakan untuk penelitian yaitu daun kecombrang (Etlingera elatior (Jack) R.M.Sm) yang diambil dari Kabupaten Subang, etanol 96\% (PT. Dipa Prasada Husada), aqudest.

\subsection{Metode Standarisasi Simplisia Parameter Spesifik}

\section{Kadar Sari Larut Air}

5 gram serbuk simplisia dimaserasi dengan $100 \mathrm{~mL}$ cloroform $P(2,5 \mathrm{~mL}$ kloroforom dalam $1000 \mathrm{~mL}$ aquadest) selama 24 jam menggunakan labu bersumbat sambil sesekali dikocok, kemudian didiamkan. Disaring, $20 \mathrm{mlL}$ filtrat diuapkan dalam cawan dangkal berdasar rata (yang telah ditara) di atas penangas air hingga kering, sisa dipanaskan pada suhu $105^{\circ} \mathrm{C}$ hingga bobot tetap. Kadar dihitung dalam persen terhadap bahan yang telah dikeringkan di udara (Mayasari, 2018; Junaid, 2016).

\section{Kadar Sari Larut Etanol}

5 gram serbuk simplisia dimaserasi dengan $100 \mathrm{~mL}$ cloroform $P(2,5 \mathrm{~mL}$ kloroforom dalam $1000 \mathrm{~mL}$ aquadest) selama 24 jam menggunakan labu bersumbat sambil sesekali dikocok, kemudian didiamkan. Disaring, $20 \mathrm{mlL}$ filtrat diuapkan dalam cawan dangkal berdasar rata (yang telah ditara) di atas penangas air hingga kering, sisa dipanaskan pada suhu $105^{\circ} \mathrm{C}$ hingga bobot tetap. Kadar dihitung dalam persen terhadap bahan yang telah dikeringkan di udara (Mayasari, 2018; Junaid, 2016).

\section{Skrining Fitokimia \\ Uji Flavonoid}

Sampel dalam bentuk serbuk atau ekstrak pada tabung reaksi ditambahkan air dan didihkan. Setelah itu, disaring dan filtratnya digunakan untuk pengujian. Filtrat yang diperoleh dibagi menjadi dua bagian, bagian pertama digunakan sebagai blanko, bagian kedua ditambahkan 0,05 g serbuk $\mathrm{Mg}, 1 \mathrm{~mL}$ larutan asam klorida dan beberapa tetes larutan amil alkohol, kemudian dikocok dengan kuat. Hasil positif ditunjukan oleh warna kuning atau jingga tertarik oleh amil alkohol (Febriyanti dkk., 2014).

\section{Uji Alkaloid}

Sampel dalam bentuk serbuk atau ekstrak dibasakan dengan amonia encer (10\%) digerus dalam mortir, kemudian ditambahkan kloroform sambil terus digerus. Lapisan kloroform dipipet sambil disaring, kemudian ditambahkan $\mathrm{HCl} 2 \mathrm{~N}$. Filtrat dibagi tiga bagian. Bagian pertama digunakan sebagai blanko, bagian kedua ditetesi dengan larutan pereaksi Mayer terbentuk endapan menggumpal berwarna putih atau kuning. Bagian ketiga ditetesi larutan pereaksi Dragendroff, reaksi positif ditandai terbentuknya warna merah atau jingga (Febriyanti dkk., 2014).

\section{Uji Saponin}

Sampel dalam bentuk serbuk atau ekstrak dipanaskan dan ditambahkan air. Setelah dingin ekstrak dikocok selama 1 menit. Jika adanya saponin maka ekstrak akan membentuk busa sekurangkurangnya selama 1 menit kemudian ditambahkan asam klorida 1 N. Bila busa yang terbentuk tetap stabil, maka sampel 
positif mengandung saponin (Gangga dkk., 2017).

\section{Tanin dan Polifenol}

Sampel ditambahkan aquadest panas, kemudian diaduk dan didinginkan. Tambahkan 5 tetes $\mathrm{NaCl}$ 10\% kemudian disaring. Filtrat dibagi menjadi 3 bagian $A$, $B$ dan $C$. Filtrat A digunakan sebagai blanko, kedalam filtrat B ditambahkan 3 tetes pereaksi $\mathrm{FeCl}_{3} 1 \%$ dan kemudian filtrat $C$ ditambahkan larutan gelatin $1 \%$, kemudian diamati perubahan yang terjadi. Jika terbentuk warna hijau kehitaman pada filtrat B adanya tanin terhidrolisis, jika terbentuk hijau kecoklatan pada B menunjukan adanya tanin terkondensasi dan terbentuknya warna selain warnawarna ini menunjukan adanya senyawa polifenol (Endarini, 2016).

\section{Parameter Non Spesifik}

\section{Susut Pengeringan}

Simplisia ditimbang 1-2 $g$, dimasukkan kedalam botol timbang dangkal bertutup sebelumnya telah dipanaskan pada suhu $105^{\circ} \mathrm{C}$ selama 30 menit dan telah ditara. Sebelum ditimbang, simplisia serbuk diratakan dalam botol timbang dengan digoyanggoyangkan, kemudian dimasukan kedalam oven, buka tutupnya. Pengeringan dilakukan pada suhu penetapan yaitu $105^{\circ} \mathrm{C}$ hingga diperoleh bobot tetap lalu ditimbang. Sebelum pengeringan, botol dibiarkan dalam keadaan tertutup mendingin dalam desikator hingga suhu kamar (Depkes, 2014).

\section{Kadar Air}

Masukan toluen dan air ke dalam labu kemudian dikocok. Campuran didestilasi sampai tidak ada lagi air yang menetes, ukur volume air yang terdestilasi. Masukan toluen jenuh air dan $5 \mathrm{~g}$ sampel ke dalam labu, pasang rangkaian alat kemudian didestilasi kembali sampai tidak ada air yang menetes. Kadar air dihitung terhadap bahan awal dalam \% v/b (Depkes, 2014).

\section{Kadar Abu Total}

Simplisia ditimbang sebanyak 2 gram dan dimasukkan kedalam krus yang telah dikonstankan. Kemudian pijarkan perlahan hingga suhu $600^{\circ} \mathrm{C}$, lalu dinginkan dan timbang hingga bobot konstan, kadar abu total dihitung terhadap berat bahan uji, dinyatakan dalam \% b/b (Depkes 2000; Utami dkk 2017; Zainab dkk 2016). Simplisia sebanyak 2 gram ditimbang dan dimasukkan kedalam krus yang telah dipijar dan ditara. Kemudian simplisia dipijarkan menggunakan tanur.

\section{Pembuatan Ekstrak}

Pembuatan ekstrak daun kecombrang dilakukan dengan metode maserasi. Selama proses pembuatan, ekstraksi direndam menggunakan pelarut etanol $96 \%$ sampai seluruh serbuk simplisia terendam. Maserasi berlangsung selama 3 kali 24 jam sambil sesekali dilakukan pengadukan. Setelah itu ekstrak yang diperoleh dilakukan penyaringan untuk memisahkan filtrat dan residu. Kemudian, filtrat yang terkumpul diuapkan menggunakan rotary evaporator sehingga didapatkan ekstrak kental daun kecombrang (Kusumawati dkk 2015; Mu'ani H dan Purwati, 2019).

\section{Pembuatan Sediaan Uji}

Ekstrak daun kecombrang di timbang sebanyak 2,5 g, $5 \mathrm{~g}$ dan $10 \mathrm{~g}$. Larutkan masing-masing ekstrak dengan etanol $96 \%$ sampai $100 \mathrm{~mL}$ sehingga diperoleh konsentrasi 2,5\%, 5\% dan 10\%. 
Pengujian Aktivitas Pertumbuhan Rambut

Pengujian aktivitas daun kecombrang terhadap pertumbuhan rambut kelinci jantan menggunakan metode Tanaka et al., (1980). Sebelum pengujian kelinci diadaptasi terlebih dahulu selama 1 minggu. Kemudian punggung kelinci dibersihkan dari rambut dengan cara dicukur hingga bersih, dibagi menjadi 3 bagian daerah pengolesan yang masing-masing berbentuk segi empat dengan luas area $2,5 \times 2,5 \mathrm{~cm}$ dan jarak antar daerah $1 \mathrm{~cm}$. Sebelum dilakukan pengolesan, punggung kelinci yang telah dicukur diolesi etanol $96 \%$ sebagai antiseptik (Sulastri dkk., 2019). Uji aktivitas pertumbuhan rambut dilakukan pada 6 kelompok uji, yaitu konsentrasi ekstrak 2,5\%, konsentrasi ekstrak 5\%, konsentrasi ekstrak 10\%, kontrol normal, kontrol negatif dan kontrol positif. Kontrol normal kelompok yang hanya dicukur rambutnya tanpa pengolesan sediaan. Kontrol negatif kelompok yang diberikan etanol. Kontrol positif dioleskan sediaan yang ada dipasaran yaitu minoxidil $2 \%$. Konsentrasi
1 diolesi ekstrak etanol daun kecombrang 2,5\%, konsentrasi 2 diolesi ekstrak etanol daun kecombrang 5\%, konsentrasi 3 diolesi ekstrak daun kecombrang $10 \%$. Sediaan uji dioleskan kepunggung kelinci sebanyak $1 \mathrm{~mL}$ dua kali sehari pada masing-masing perlakuan selama 28 hari (Febriani dkk., 2016; Meilani Ayu dkk., 2019). Daerah pengolesan pada punggung kelinci dilakukan secara acak, karena kemungkinan tiap daerah memiliki pertumbuhan rambut yang berbeda-beda. Dengan pengacakan ini diharapkan aktivitas pertumbuhan rambut semua daerah dengan perlakuan yang berbeda dapat terwakili. Pengamatan dilakukan dengan mengambil 6 helai rambut kelinci pada tiap bagian setiap 7 hari sekali, diukur panjangnya pada hari ke-7, ke-14, ke-21 dan ke-28. Panjang rambut diukur dengan menggunakan jangka sorong dan pada hari ke-28 rambut kelinci dikucur kemudian ditimbang bobot rambutnya. Laju pertumbuhan rambut dan bobot rambut kelinci di analisa secara statistik menggunakan software SPSS 23 (Vania dkk., 2019). 

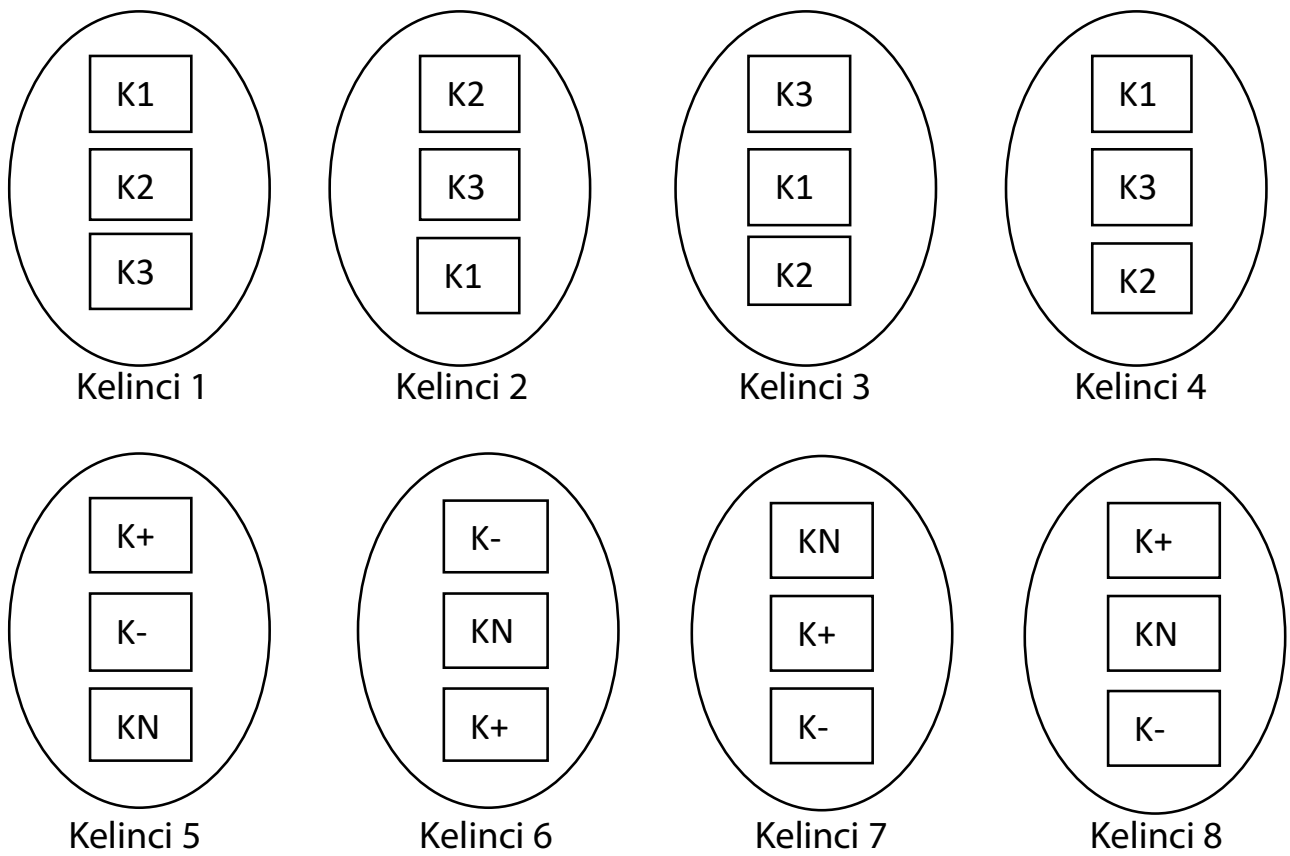

Gambar 1. Daerah Pengolesan Punggung Kelinci

\section{Keterangan:}

$\mathrm{K} 1=$ Konsentrasi 1 $(2,5 \%)$
$\mathrm{K} 2=$ Konsentrasi 2 (5\%)
$\mathrm{K} 3=$ Konsentrasi 3 $(10 \%)$

$\mathrm{K}+\quad=\quad$ Kontrol Positif (Minoxidil 25\%)

$\mathrm{K}-\quad=$ Kontrol Negatif (Etanol 96\%)

$\mathrm{KN}=$ Kontrol Normal (Tidak diberikan apapun)

\section{HASIL DAN PEMBAHASAN}

\section{Parameter Spesifik}

\section{Kadar Sari Larut dalam Air dan Etanol Simplisia}

Kadar sari larut air diperoleh sebesar $15,25 \%$ dan kadar sari larut etanol 16,9\%. Hasil yang diperoleh memperlihatkan bahwa senyawa dari daun kecombrang lebih banyak larut dalam etanol dibanding air serupa dengan yang dilakukan (Leorita Mesi et al, 2018), hal ini disebabkan karena air bersifat polar dan etanol bersifat polarnon polar.

\section{Skrining Fitokimia}

Dari pengujian skrining fitokimia menunjukkan bahwa pada serbuk simplisia daun kecombrang mengandung senyawa flavonoid, saponin. Dan pada ekstrak etanol daun kecombrang mengandung senyawa alkaloid, flavonoid, saponin, tanin (Leorita Mesi et al, 2018).

\section{Parameter Non Spesifik Susut Pengeringan}

Parameter susut pengeringan pada dasarnya adalah pengukuran sisa zat setelah pengeringan pada temperatur $105^{\circ} \mathrm{C}$ sampai berat konstan, yang dinyatakan sebagai nilai persen (Depkes RI, 2000). Massa yang dapat hilang karena pemanasan ini meliputi molekul air, minyak atsiri dan pelarut (Utami, 2017). Hasil susut pengeringan pada daun kecombrang yaitu 9,4\%. Begitupun dalam (Pramiastuti O et al., 2018) didapatkan hasil susut pengeringan dari daun kecombrang yaitu $<10 \%$.

\section{Kadar Air}

Tujuan dari kadar air itu sendiri yaitu memberikan batasan minimal atau rentang tentang besarnya kandungan air didalam suatu bahan. Kadar air yang tinggi dapat memicu tumbuhnya mikroorganisme dan dapat terjadi 
pembusukan. Semakin tinggi kadar air, maka semakin mudah untuk ditumbuhi jamur, kapang sehingga dapat menurunkan aktivitas biologi ekstrak dalam masa penyimpanan (Najib A dkk., 2017). Kadar air yang didapatkan pada simplisia daun kecombrang adalah $6 \%$ yang berarti $<10 \%$ sama halnya dengan yang didapatkan oleh Pramiastuti $\mathrm{O}$ et al., 2018.

\section{Kadar Abu Total}

Tujuan dilakukannya pengujian kadar abu adalah untuk memberikan gambaran kandungan mineral internal dan eksternal yang berasal dari proses awal sampai terbentuknya ekstrak (Depkes RI., 2000). Tingginya suatu kadar abu menunjukkan tingginya kandungan mineral internal didalam simplisia itu sendiri. Pada pengujian ini didapatkan hasil $4,51 \%$.

\section{Ekstraksi}

Rendemen ekstrak kental yang didapatkan dari daun kecombrang (Etlingera elatior (Jack) R.M.Sm.) yaitu $15,8 \%$.

\section{Pengujian Aktivitas Pertumbuhan Rambut}

Pemberian minoxidil dapat secara langsung meningkatkan pertumbuhan rambut melalui papila dermal dan sel epitel (Choi, dkk. 2018) selain itu minoxidil dapat membuka jalan kalium serta bersifat sebagai vasodilator yang dapat memperlebar pembuluh darah sehingga oksigen, nutrisi dan darah lebih banyak masuk kedalam folikel rambut yang memungkinkan pertumbuhan rambut menjadi lebih cepat (Rossi, dkk. 2012). Adaptasi pada kelinci dilakukan agar kelinci tidak mengalami stres saat berada lingkungan barunya. Pengujian dilakukan pada kelinci jantan karena kelinci jantan lebih adaptif terhadap lingkungan dan tidak mudah stress (Indriaty dan Sulastri, 2016). Pada uji aktivitas pertumbuhan rambut dilihat berdasarkan parameter uji yaitu rata-rata panjang rambut dan bobot rambut kelinci. Data rata-rata panjang pertumbuhan rambut dapat dilihat pada Tabel 1.

Tabel 1. Laju Pertumbuhan Rambut

\begin{tabular}{lccccc}
\hline \multirow{2}{*}{ Perlakuan } & \multicolumn{5}{c}{ Panjang Petumbuhan Rambut dalam cm } \\
\cline { 2 - 5 } & Hari ke-7 & $\begin{array}{c}\text { Hari ke- } \\
\mathbf{1 4}\end{array}$ & $\begin{array}{c}\text { Hari } \\
\text { ke-21 }\end{array}$ & $\begin{array}{c}\text { Hari } \\
\text { ke-28 }\end{array}$ & Rata-rata panjang rambut \\
\hline Kontrol normal & 0,38 & 0,45 & 0,59 & 1,07 & $0,62 \pm 0,31$ \\
Kontrol negatif & 0,40 & 0,48 & 0,64 & 1,08 & $0,65 \pm 0,30$ \\
Kontrol positif & 1,25 & 1,82 & 2,36 & 2,76 & $2,05 \pm 0,65$ \\
Konsentrasi2,5\% & 0,58 & 0,75 & 1,17 & 1,45 & $0,99 \pm 0,40$ \\
Konsentrasi 5\% & 0,54 & 0,79 & 1,38 & 1,72 & $1,11 \pm 0,54$ \\
Konsentrasi 10\% & 0,81 & 1,21 & 1,64 & 1,92 & $1,40 \pm 0,49$ \\
\hline
\end{tabular}

Berdasarkan Tabel 1. bahwa hasil aktivitas laju pertumbuhan rambut dilakukan dengan membandingkan nilai laju pertumbuhan rambut terhadap kontrol negatif. Hasil menunjukan bahwa aktivitas dari K1, K2 dan K3 lebih kecil dibandingkan dengan kontrol positif. Dari ketiga konsentrasi uji diketahui bahwa K3 memiliki aktivitas lebih besar jika dibandingkan dengan $\mathrm{K} 1$ dan $\mathrm{K} 2$, sehingga dapat dikatakan semakin besar konsentrasi ekstrak daun kecombrang yang diberikan pada tiap perlakuan, maka semakin baik aktivitas yang diberikan juga dalam 
mempercepat pertumbuhan rambut. Berdasarkan penelitian yang dilakukan Jubaidah dkk (2018) kandungan flavonoid bekerja dengan merangsang pertumbuhan rambut, menebalkan epidermis dan memulihkan pertumbuhannya, dimana epidermis yang menipis secara alami seiring dengan proses penuaan memicu terjadinya kerontokan. Serta dapat memperkuat pembuluh darah yang dapat memperluas miniatur folikel, dengan begitu sistem sirkulasi ke folikel rambut membaik dan memungkinkan masuknya nutrisi dan oksigen ke dalam folikel rambut (Bylka 2013; Thorat 2010). Flavonoid yang terkandung dalam daun kecombrang yaitu jenis kaemferol yang bersifat sebagai antibakteri yang dapat menekan pertumbuhan bakteri serta quersetin sebagai antioksidan yang dapat menangkal radikal bebas (Farida \& Maruzy, 2016). Setelah itu langkah selanjutnya dilakukan pengamatan terhadap bobot rambut dengan mencukur satu kali pada setiap daerah uji masing-masing perlakuan dihari ke-28, kemudian ditimbang (Aini Q, 2017). Hasil penimbangan rata-rata bobot rambut dapat dilihat pada Tabel 2.

Tabel 2. Hasil Rata-rata Bobot Rambut

\begin{tabular}{lc}
\hline Perlakuan & $\begin{array}{c}\text { Rata-rata bobot } \\
\text { rambut }\left(\mathbf{g} / \mathbf{c m}^{\mathbf{2}}\right) \pm \mathbf{S D}\end{array}$ \\
\hline Kontrol Normal & $0,07 \pm 0,88$ \\
Kontrol Negatif & $0,08 \pm 0,22$ \\
Kontrol Positif & $0,12 \pm 0,08$ \\
Konsentrasi 2,5\% & $0,09 \pm 0,08$ \\
Konsentrasi 5\% & $0,09 \pm 0,03$ \\
Konsentrasi 10\% & $0,11 \pm 0,03$ \\
\hline
\end{tabular}

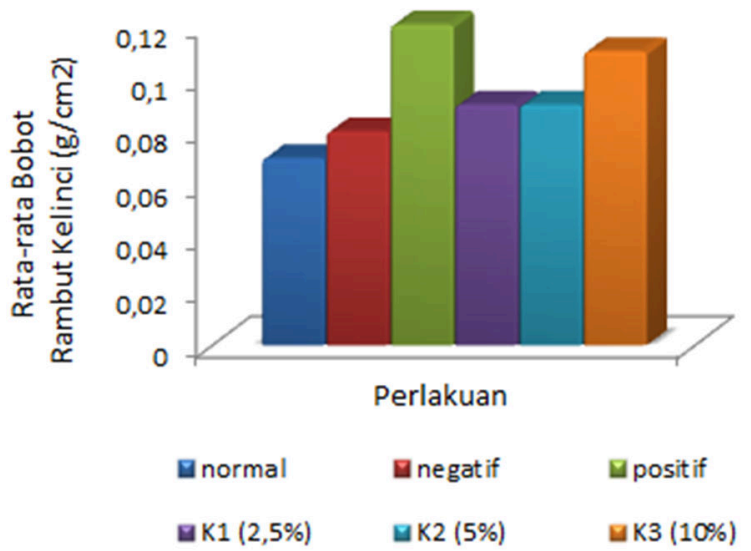

Gambar 2. Rata-rata Bobot Rambut Kelinci

Dalam Tabel 2 rata-rata bobot rambut kelinci pada hari ke-28 menunjukkan bahwa K3 (10\%) memiliki bobot paling berat jika dibandingkan dengan K1 (2,5\%) dan K2 (5\%). Namun jika dibandingkan dengan kontrol positif bobot rambut konsentrasi 3 lebih ringan. K3 (10\%) memiliki nilai bobot rata-rata rambut yang mendekati nilai dari bobot rata-rata kontrol positif dikarenakan pada konsentrasi $10 \%$ terdapat senyawa aktif yang lebih besar pelepasannya seperti flavonoid.

\section{Hasil Analisis Statistik Laju Pertumbuhan Rambut}

Berdasarkan hasil uji normalitas Shapiro-Wilk diperoleh nilai sig. > 0,05 sehingga Ho diterima, menandakan bahwa semua sampel diambil dari populasi yang terdistribusi normal. selanjutnya dilakukan uji homogenitas varian levene menunjukkan nilai signifikansi $>0,05$ yaitu 0,241 sehingga Ho diterima, artinya semua varian homogen. Karena sampel terdistribusi normal dan semua varian homogen, maka selanjutnya dilakukan uji ANOVA. Berdasarkan uji menunjukkan nilai signifikansi < 0,05 yaitu 0,04 sehingga Ho ditolak. Hal ini menandakan adanya perbedaan aktivitas pada setiap kelompok. 
Lalu dilakukan uji LSD (Least Significant Difference) untuk menentukan adanya perbedaan antar kelompok. Berdasarkan hasil uji LSD kontrol negatif tidak memiliki perbedaan bermakna dengan kontrol normal, K1 dan K2 namun memiliki perbedaan bermakna dengan K3 dan kontrol positif. Hal ini menunjukan kontrol negatif tidak memiliki aktivitas terhadap pertumbuhan rambut, artinya aktivitas pertumbuhan rambut tidak dipengaruhi oleh pelarut yang digunakan pada ekstrak etanol daun kecombrang. Selanjutnya hasil analisis LSD menyatakan bahwa K3 tidak memiliki perbedaan yang bermakna dengan kontrol positif, yang artinya K3 memiliki aktivitas pertumbuhan rambut yang hampir sama dengan kontrol positif.

\section{Hasil Analisis Statistik Rata-rata Bobot Rambut}

Berdasarkan hasil uji normalitas Shapiro-Wilk diperoleh nilai sig. > 0,05 sehingga Ho diterima, menandakan bahwa semua sampel diambil dari populasi yang terdistribusi normal. selanjutnya dilakukan uji homogenitas varian levene menunjukkan nilai signifikansi $>0,05$ yaitu 0,052 sehingga Ho diterima, artinya semua varian homogen. Kemudian sampel terdistribusi normal dan semua varian homogen, maka selanjutnya dilakukan uji ANOVA. Berdasarkan uji menunjukkan nilai signifikansi $>0,05$ yaitu 0,654 sehingga $\mathrm{Ho}$ diterima yang berarti tidak terdapat perbedaan. Perbedaan tidak bermakna tersebut terjadi karena kelebatan rambut pada kontrol normal, kontrol negatif, konsentrasi 2,5\%, konsentrasi $5 \%$ dan konsentrasi $10 \%$ yang mengandung ekstrak daun kecombrang memiliki kelebatan rambut yang hampir sama, sehingga bobot rambut tidak dapat dijadikan sebagai parameter pertumbuhan rambut karena pada semua kontrol dan kelompok uji tidak ada perbedaan bermakna. Namun jika dilihat dari Gambar 2 konsentrasi 10\% ekstrak etanol daun kecombrang memiliki bobot rata-rata rambut yang mendekati bobot rata-rata kontrol positif, hal ini terjadi karena pada konsentrasi tersebut pelepasan zat berkhasiat/zat aktifnya lebih besar.

\section{KESIMPULAN}

Berdasarkan hasil penelitian yang telah dilakukan dapat disimpulkan bahwa ekstrak etanol daun kecombrang dengan konsentrasi 10\% memiliki aktivitas sebagai penyubur rambut yang paling baik dengan rata-rata panjang rambut $1,40 \mathrm{~cm}$. Maka semakin tinggi konsentrasi semakin baik bagi pertumbuhan rambut.

\section{UCAPAN TERIMA KASIH}

Terimakasih kepada orang tua yang telah mendanai penelitian ini, dan terimakasih kepada dosen, laboran, teman-teman dan semua pihak yang telah membantu sehingga penelitian ini dapat berjalan dengan baik.

\section{DAFTAR PUSTAKA}

Aini, Q. 2017. Uji Aktivitas Pertumbuhan Rambut Kelinci Jantan Dari Sediaan Hair Tonic Yang Mengandung Ekstrak Etanol Daun Mangkokan (Nothopanax scutellarium L). JFL: Jurnal Farmasi Lampung, 6(2).

Aprilia, T. 2017. Uji Picu Pertumbuhan Rambut Kelinci Dengan Ekstrak Etanol Daun Binahong (Anredera cordifolia (Ten.) Steenis). (Skripsi). Jurusan Biologi FMIPA. Unila. Lampung.

Bylka W., Znajdek-Awizen P., Studzinska Sroka E., Brzenzinska M, 2013. Centella asiatica in Cosmetology, Postep Derm Alergol; 30(1) : 46-49.

Choi, N., Shin, S., Song, S. U., dan Sung, J. H. 2018. Minoxidil promotes hair growth through stimulation of growth factor 
release from adipose-derived stem cells. International Journal of Molecular Sciences, 19(3), 1-15.

Depkes RI. 2000. Parameter Standar Umum Ekstrak Tumbuhan Obat. Direktorat Jendral Pengawasan Obat dan Makanan. Jakarta.

Depkes Rl, 2014. Farmakope Indonesia Edisi V. Departemen Kesehatan Republik Indonesia, Jakarta.

Diana W, 2014. Penggunaan Ekstrak Buah Alpukat dan Madu Sebagai Bahan Aktif Hair Tonic Untuk Rambut Rontok, EJournal, 3(1), 226 - 235.

Endarini, L.H. 2016. Farmakognisi dan Fitokimia. Jakarta: Pusdik SDM Kesehatan.

Farida, S \& Maruzy, A 2016. SECARA TRADISIONAL , FITOKIMIA DAN AKTIVITAS FARMAKOLOGINYA Torch Ginger : A review of Its Traditional Uses , Phytochemistry and Pharmacology. Jurnal Phytochemistry and Pharmacology. 9(1) 19-28.

Febriani ., Elya B, \& Jufri M, 2016. Uji aktivitas dan keamanan hair tonic ekstrak daun kembang sepatu (Hibiscus rosasinensis) pada pertumbuhan rambut kelinci, Jurnal Farmasi Indonesia, 8(1): $259-270$.

Febriyanti M, Supriyatna \& Abdulah R, 2014. Kandungan Kimia dan Aktivitas Sitotoksik Ekstrak dan Fraksi Herba Anting-anting terhadap Sel Kanker Payudara MCF-7, Jurnal Farmasi Indonesia, 7(1), 19 - 26.

Gangga E , Purwati R, dan F Yunahara, Kartiningsih, 2017. Penetapan Parameter Mutu Ekstrak yang Memiliki Aktivitas sebagai Antioksidan dari Daun Cincau Hijau (Cyclea barbata L.Miers.), Jurnal IImu Kefarmasian Indones, 15(2): 236 - 243.

Indriaty S, Sulastri L, 2016. Uji Aktivitas Ekstrak Air Akar Manis ( Glycyrrhiza glabra L .) sebagai Penyubur Rambut pada Kelinci Jantan, Jurnal Farmasi Muhammadiyah Cirebon, $24-30$.

Jubaidah S, I Ria, Sa'adah H, W Heri, 2018. Formulasi Dan Uji Pertumbuhan Rambut Kelinci Dari Sediaan Hair Tonic Kombinasi Ekstrak Daun Seledri (Apium graveolens Linn) Dan Daun
Mangkokan (Polyscias scutellaria (Burm.f.) Fosberg), Jurnal Ilmiah Manuntung, 4(1), 8- 14.

Kusumawati, E., Supriningrum, R., \& Rozadi R, 2015. Uji Aktivitas Antibakteri Ekstrak Etanol Daun Kecombrang Etlingera elatior (Jack) R. M. Sm Terhadap Salmonella typhi, Jurnal IImiah Manuntung, 1(1), 1-7.

Leorita Mesi et al. 2018. Aktivitas Antioksidan dan Toksisitas Akut Ekstrak Etanol Buah, Daun, Batang dan Rimpang Tanaman Wualae (Etlingera elatior (Jack) R.M. Smith).Pharmauho.Volume 4(2)hal: 36-39.

Mayasari U \& Laoli M Teokarsa. 2018. Karakterisasi Simplisia Dan Skrining Fitokimia Daun Jeruk Lemon (Citrus limon (L.) Burm.f.), Klorofil, 2(1): 7-13.

Meilani, A., Kanedi, M., Yulianty, Y., \& Nurcahyani, N. 2019. Pengujian Efektivitas Ekstrak Biji Pepaya (Carica papaya L.) Terhadap Pertumbuhan Bulu Kelinci (Oryctolagus cuniculus (Linnaeus, 1758). Inovasi Pengembangan: Jurnal Jurnal, 7(3), 221-228

Mu'ani, H dan Purwati. 2019. Uji Stabilitas Fisik Dan Uji Aktivitas Sediaan Hair Tonic Dari Ekstrak Etanol 96\% Daun Kangkung (Ipomoea aquatica Forsk.) Pada Rambut Kelinci Jantan (New Zealand White). Indonesia Natural Research Pharmaceutical Journal. Vol 4(2)pp. 23-31.

Najib A, Malik A., Ahmad, AR, Handayani, V., Syarif, RA, \& Waris, 2017. Standarisasi Ekstrak Air Daun Jati Belanda dan Teh Hijau, Jurnal Fitofarmaka Indonesia, 4(2): $241-245$.

Pramiastuti O, Zen D.A, P Bayu Aji. 2018. Penetapan Kadar Total Fenolik dan Uji Aktivitas Antioksidan Ekstrak Etanol 96\% Daun Kecombrang (Etlingera elatior) Dengan Metode 2,2-Difenil-1Pikrilhidazil (DPPH). Jurnal Farmasi dan Sains Indonesia. Volume 1(2), hal: 42-55

Rossi, A., Cantisani, C., Melis, L., lorio, A., Scali, E., \& Calvieri, S. 2012. Minoxidil Use in Dermatology, Side Effects and Recent Patents. Recent Patents on Inflammation \& Allergy Drug Discovery, 6(2), 130-136. 
Sulastri L, Indrawati T, Taurhesia S, 2019. Uji Aktivitas Penyubur Rambut Gel Kombinasi Ekstrak Air Teh Hijau Dan Herba Pegagan, Medical Sains, 4(1): 19 34.

Supomo Junaid, R. S. Dan R. (2016). (Callicarpa Longifolia Lamk.) Characterization And Leaves Phytochemical Screening Kerehau ( Callicarpa Longifolia Lamk .). Jurnal Kimia Mulawarman, 13.

Tanaka, S. Saito, M., Tabata, M. 1980. Bioassay of Crude Drugs for Hair Growth Promoting Activity in Mice by a New Simple Method. Faculty of Pharmaceutical Sceinces Kyoto University, Japan.

Thorat R.M , 2010. Herbal Treatment For Hair Loss, International Journal of Pharmacy \& Technology, 2(4) : 497-503.

Turnip, Heltimala, 2019. Kajian Manfaat Tanaman Agroforestri Kecombrang (Etlingera elatior) Sebagai Obat dan Pangan Oleh Masyarakat di Kecamatan Kabanjahe, Kabupaten Karo. Skripsi. Fakultas Kehutanan. Universitas Sumatera Utara: Medan

Umborowati MA, Rahmadewi, 2012. Rambut Rontok Akibat Lingkungan dan Kosmetik (Environment and Cosmetic
Induced Hair Loss). Berkala IImu Kesehatan Kulit dan Kelamin, 24(1): 35 42.

Utami, Y, P., Umar, A. H., Syahruni, R., \& Kadullah, I, 2017. Standarisasi Simplisia dan Ekstrak Etanol Daun Leilem (Clerodendrum minahassae Teisjm. \& Binn.), Journal of Pharmaceutical and Medicinal Sciences, 2(1): 32 - 39.

Vania I, N Tita, Rahayuningsih Nur, 2019. Uji Aktivitas Ekstrak Etanol Daun Pandan Wangi (Pandanus amaryllifolius Roxb.) Sebagai Hair Tonic Pada Kelinci Jantan Galur Lokal, Pharmacoscript, 1(2): 5767.

Yeats H. 2015. The history and cultivation of Etlingera the torch gingers at the royal botanic garden edinburgh, The Jurnal of Botanical Garden Horticulture, (11):71-85.

Zainab, Z., Gunanti, F., Witasari, H. A, Edityaningrum, C. A., Mustofa, M., \& Murrukmihadi, M. 2016. Penetapan Parameter Standarisasi Non Spesifik Ekstrak Etanol Daun Belimbing Wuluh (Averrhoa bilimbi L.). Prosiding Rakernas dan Pertemuan IImiah Tahunan Ikatan Apoteker Indonesia. 210-214.

Copyright $\odot 2020$ The author(s). You are free to Share - copy and redistribute the material in any medium or format. Adapt - remix, transform, and build upon the material Under the following terms: Attribution - You must give appropriate credit, provide a link to the license, and indicate if changes were made. You may do so in any reasonable manner, but not in any way that suggests the licensor endorses you or your use. NonCommercial - You may not use the material for commercial purposes. ShareAlike - If you remix, transform, or build upon the material, you must distribute your contributions under the same license as the original. No additional restrictions - You may not apply legal terms or technological measures that legally restrict others from doing anything the license permits. 